Исходя из вышесказанного, можно сделать вывод, что школа классического танца на Алтае продолжает развиваться, бережно сохраняет и преумножает традиции своих первопроходцев, целенаправленно воспитывает в своих учениках любовь к классическим образцам, искусству высокого танца, осознание роли классики в формировании личности хореографа профессионала.

Огромные возможности классического танца можно обнаружить и в формировании системы профессиональных компетенций будущих педагогов-хореографов. Прежде всего, классический танец направлен на формирование целого комплекса художественного (условного) языка танца, отличного от бытовой пластики, который эстетически базируется на совершенных навыках владения физическим аппаратом исполнителя. Но при исполнении классических «па» нельзя думать только о технике движений. В мышечной памяти исполнителя на уровне закрепленного двигательного навыка остается не только внешняя форма движения, но и его внутреннее эмоционально-психологическое содержание.

\section{Список литературы}

1. Уральская В. «Пахита» или путь к себе самим // Балет. 2009. № 1.С. 15-16.

2. Сибирякова Л. В. Балетмейстеры Народного театра балета Дома культуры Барна- ульского меланжевого комбината // Ученые записки (Алтайская государственная академия культуры и искусств). Танцевальное искусство и образование. 2018. № 4 (18). С. 52-57.

3. Смолянинова Н. И. Роль М. А. Зарайской в становлении и развитии народного театра балета // Ученые записки (Алтайская государственная академия культуры и искусств). Танцевальное искусство и образование. 2018. № 4 (18). C. 58-63.

4. Савченко М. В. Творчество Л. С. Силантьевой - педагога, балетмейстера, руководителя народного театра балета «Вдохновение» // Ученые записки (Алтайская государственная академия культуры и искусств). Танцевальное искусство и образование. 2018. № 4 (18). C. $43-51$.

5. Бурцева Г. В. Воспоминания об организации балетной студии в Алтайском государственном театре музыкальной комедии // Ученые записки (Алтайская государственная академия культуры и искусств). Танцевальное искусство и образование. 2018. № 4 (18). С. 29-36.

6. Рылеева Н. Г. Педагогическая деятельность Н. Н. Кровяковой в народном ансамбле классического танца «Эос» // Ученые записки (Алтайская государственная академия культуры и искусств). Танцевальное искусство и образование. 2018. № 4 (18). С. 39-43.
Е. В. Ваганова, кандидат исторических наук, доцент Восточно-Сибирский государственный институт культуры (Улан-Удэ, Россия) ev_vaganova@mail.ru

С. Э. Эрдынеева Восточно-Сибирский государственный институт культуры (Улан-Удэ, Россия) sneg_idet97@bk.ru

\title{
ЛИЧНЫЙ АРХИВНЫЙ ФОНД КСЕНИИ МАКСИМОВНЫ ГЕРАСИМОВОЙ КАК ИСТОРИЧЕСКИЙ ИСТОЧНИК
}

Аннотация. Данная статья посвящена личному архивному фонду Ксении Максимовны Герасимовой, хранившемуся в Центре восточных рукописей и ксилографов Института монголоведения, буддологии и тибетологии Сибирского отделения Российской академии наук. Основное содержание исследования представляют документы личного характера и документы научной и общественной деятельности ученого. В работе более подробно описаны блокадные дневники К. М. Герасимовой, которые несут большую ценность и являются ценным историческим источником.

Ключевые слова: архив, личный архивный фонд, исторический источник, ученый, Герасимова Ксения Максимовна, буддология, музейное дело, Музей истории Бурятии им. М. Н. Хангалова, кониุепนฺия. 
«Архив представляет собой совокупность архивных документов, а также архивное учреждение или структурное подразделение учреждения, организации и предприятия, осуществляющее прием и хранение архивных документов в интересах пользователей». В этом определении присутствуют три значения понятия «архив». Это собрание документов, также можно соотнести как синонимы - фонд или коллекция; архивное учреждение, т. е. архив, осуществляющий государственное хранение документов и структурная часть учреждения. Внутри архивов все документы распределяются по архивным фондам. Определение архивного фонда трактуется так: это «совокупность архивных документов, исторически или логически связанных между собой». Архивный фонд также обозначается как совокупность всех документов, образовавшихся деятельностью организации, учреждения, предприятия или лица [1, с. 7-8].

Бурятский ученый комитет (Буручком) ныне Институт монголоведения, буддологии и тибетологии Сибирского отделения Российской академии наук (далее - ИМБТ СО РАН) был основан 1 июля 1922 г. как первое научноисследовательское учреждение в Бурятии. В мае 1929 г. был преобразован в Бурят-монгольский государственный институт культуры (далее БМГИК). Также он носил названия: в 1936 г. Государственный институт языка, литературы и истории (ГИЯЛИ), в 1944 г. - БурятМонгольский научно-исследовательский институт культуры и экономики (БМНИИКЭ), в 1949 г. - Бурят-Монгольский научноисследовательский институт культуры (БМНИИК). В 1958 г. на базе Института культуры создан Бурятский комплексный научноисследовательский институт (БКНИИ) СО АН СССР. В 1966 г. был преобразован в Бурятский филиал СО АН СССР в составе двух крупных подразделений - Бурятского института общественных наук СО АН СССР (далее - БИОН БФ CO АН СССР) и Бурятского института естественных наук СО АН СССР (БИЕН СО АН СССР). В 1997 г. БИОН СО РАН переименован в Институт монголоведения, буддологии и тибетологии Сибирского отделения Российской Академии наук (далее - ИМБТ СО РАН).

Ксения Максимовна Герасимова - ученыйвостоковед, религиовед, доктор исторических наук, Заслуженный деятель науки Российской Федерации и Республики Бурятия, одна из старейших сотрудников Бурятского института общественных наук (ныне - Института монголо- ведения, буддологии и тибетологии СО РАН) [2, c. 228].

Для изучения научной и общественной деятельности К. М. Герасимовой особый интерес представляет ее личный архивный фонд, находящийся в Центре восточных рукописей и ксилографов Института монголоведения, буддологии и тибетологии СО РАН.

Фонд поступил в Центр восточных рукописей и ксилографов ИМБТ СО РАН в 2011 г. Научно-техническая обработка материалов была начата сразу с момента поступления и закончилась в 2013 г. Все дела об ученом собраны в фонд № 41 «К. М. Герасимова (1919-2011)» в двух описях. В состав архивного фонда входят материалы по тибетологии, истории, краеведению, буддийскому искусству; по музеям; большое количество документов на тибетском, английском, немецком, монгольском, французском языках; рецензии, отзывы, справки, экспедиционный материал, фотоматериалы. В архивном фонде насчитывается 1574 единиц хранения, из них документов 992 единицы, ксилографов - 150, фотоматериалов - 339, танки - 46. «Весь материал классифицирован по структурной схеме и разделен на 10 разделов:

1. Материалы к биографии фондообразователя.

2. Переписка фондообразователя.

3. Материалы по служебной и общественной деятельности.

4. Творческие материалы фондобразователя, куда входят монографии, статьи, рецензии и отзывы, доклады, выступления и тезисы, материалы по музейной деятельности, экспедиционные материалы.

5. Материалы, собранные и использованные фондообразователем. В этот раздел входят материалы на русском, немецком, английском, французском, монгольском, тибетском и других языках.

6. Словари.

7. Рабочие тетради, ежедневники, блокноты.

8. Карты, диаграммы.

9. Статьи из газет и газеты.

10. Фотоматериалы» [3, л. 7-8].

Условно материалы можно разделить на две категории: документы биографического характера и документы-свидетельства научной и общественной деятельности ученого [4, с. 139].

В архивном фонде содержатся документы об образовании и карьере Ксении Максимовны. Это табели успеваемости за 7 и 9 классы; копия 
диплома об окончании Ленинградского государственного библиотечного института им. Н. К. Крупской (№705994 от 1942 г.) по специальности «Музейное дело»; диплом об окончании Восточного факультета Ленинградского государственного ордена Ленина университета им. А. А. Жданова (№ 010164 от 1947 г.) по специальности «Монгольская филология»; диплом кандидата исторических наук, выданный решением Совета Ленинградского государственного ордена Ленина университета им. А. А. Жданова (протокол №3 от 30 марта 1953 г.); диплом доктора исторических наук, выданный решением ВАК при Совете Министров СССР (протокол №239/30 от 8 июля 1990 г.). [5, с. 25].

Здесь особый интерес представляют такие документы, как: анкета от 20 марта 1977 г., личный листок по учету кадров от 20 марта 1977 г. и автобиография, заполненные и подписанные собственноручно К. М. Герасимовой. Из этих документов, помимо информации об учебе, ученых степенях, званиях, должностях и наградах, мы узнаем личную информацию Ксении Максимовны, о ее семейном положении, о членах семьи.

В фонде К. М. Герасимовой привлекают внимание документы, относящиеся к ее матери - Акилине Ивановне Герасимовой. Она была создателем и директором Антирелигиозного музея (1937 г. по 1946 г.), который в последующем вошел в состав Верхнеудинского краеведческого музея. И, можно сказать, что благодаря ей Ксения Максимовна посвятила жизнь буддологии, тибетологии и музейному делу. В архиве сохранились личные документы А. И. Герасимовой - трудовая книжка, автобиография, справки, удостоверения, копия орденской книжки «Знак Почета». Отец - Максим Иванович (плановик-экономист), по сведениям автобиографии К. М. Герасимовой, не занимался воспитанием дочери и материально не помогал.

Свою трудовую деятельность Ксения Максимовна начала в 1942 г. в Краеведческом музее в г. Улан-Удэ, проработав там три года. Затем, прерываясь на учебу, с 1951 г. работала в сектоpe истории Бурят-Монгольского научноисследовательского института культуры, а в 1958 г., в связи с реорганизацией и созданием Бурятского комплексного научноисследовательского института СО АН СССР, перешла в Отдел зарубежного Востока и в том же году ей присвоили звание старшего научного сотрудника, о чем свидетельствует аттестат МСН №003868, решением ВАК от 11 октября 1958 г. (протокол№45/П). В 1967 г. ее назначи- ли заведующим сектором буддологии Института общественных наук Бурятского филиала CO АН СССР. Продолжением исследований истории ламаизма в 1957 г. стала публикация монографии «Ламаизм и национально-колониальная политика царизма в Забайкалье в XIX и начале XX в.», а в 1964 г. - логичным продолжением данного научного труда стало исследование под названием «Обновленческое движение бурятского ламаистского духовенства (1917-1930 г.)». В 1970 г. она была назначена заведующим проблемной группой буддологии сектора истории культуры Центральной Азии. С 1971 г. - заведующий сектором буддологии Института общественных наук БФ СО АН СССР. За годы существования сектора буддологии под редакцией К. М. Герасимовой было издано четыре сборника «Буддизм и средневековые культуры народов Центральной Азии» (1980 г.). «Буддизм и традиционные верования народов Центральной Азии» (1986 г.). «Традиционная обрядность, монгольских народов» (1992 г.) [5, c. 26]. Серьезным достижением буддологов Бурятии стала коллективная монография «Ламаизм в Бурятии XVIII - начала XX в. Структура и социальная роль альтовой системы» (1983 г.), составленная под руководством К. М. Герасимовой. В ней были обобщены многолетние исторические, архивные, полевые этнографические, религиоведческие и текстологические материалы. Сегодня все материалы, ставшие основой монографий, статей, тезисов докладов, рукописи, научные труды хранятся в ее архивном фонде К. М. Герасимовой.

Также Ксения Максимовна сыграла большую роль в развитие музейного дела Бурятии. С 1960-х гг. она фактически была нештатным сотрудником Музея истории Бурятии на общественных началах. Так, при сотрудничестве ИМБТ СО РАН с Музеем истории Бурятии им. М. Н. Хангалова, на обсуждении Ученого совета ИМБТ СО РАН ею был зачитан доклад о новой концепции экспозиции музея. И все наработки, материалы доклада и его публикация и программа научно-практического сотрудничества по строительству Национального музея истории Бурятии сохранились в архивном фонде К. М. Герасимовой $[6$, с. 205].

За время ее активной работы с музеями Бурятии она создала восемь выставок в Ленинграде, Москве, Улан-Удэ и в пяти городах Франции: «Искусство Бурятии XVIII-XIX вв.» в г. Москва в 1970 г., «Традиционное искусство бурят XIX-XX вв.», приуроченная к Дням РСФСР во Франции в 1985 г., «Бурятская 
скульптура XVIII-XX вв.» в 1992 г. и «Этнические традиции в буддизме Центральной Азии» в 1993 г. в Художественном музее им. Ц. Сампилова. К данным выставкам сохранились разработки, тематико-экспозиционные планы в архивном фонде [3, с. 6].

Кроме того, в 1992 г. её избрали председателем Бурятского отделения Всероссийской организации охраны памятников истории и культуры (далее - ВООПИК), документысвидетельства которого также имеются в архивном фонде под делами № 279, 280 «Материалы по ВООПИК (распоряжения, справки, списки руководителей районных отделений, счета, протоколы и т. д.)». Также К. М. Герасимова участвовала в работе Комитета по образованию, культуре, науке и спорта Народного хурала Республики Бурятия по основным проблемам сохранения памятников культурного наследия и включения их в актив культурной жизни народов республики [5, с. 28].

За научные достижения и вклад в развитие науки Ксения Максимовна была награждена различными почетными грамотами, благодарностями и удостоена звания «Заслуженный деятель науки Республики Бурятия» в 1980 г. и звания «Заслуженный деятель науки Российской Федерации» в 1995 г. Все ее награды и грамоты в количестве 43 шт. хранятся в фонде [2, с. 28].

Особый интерес для нас представляют блокадные дневники К. М. Герасимовой, которые также были переданы на хранение в ЦВРК ИМБТ СО РАН. Блокаду Ленинграда Ксения Максимовна застала, когда училась в Ленинградском государственном библиотечном институте им. Н. К. Крупской. Она записывала свои воспоминания о том, как и в каких условиях блокады она выживала. Записи в дневнике ведутся с сентября 1942 г. Например, вот, что пишет Ксения Максимовна о контрасте между Москвой и Ленинградом: «...Поразил контраст с горячей Москвой. В Москве бушевали анекдоты о шпионах с машинками на животе. Москвичи ошалело толпами бросались в бомбоубежище во время тревог ночных и вечерних. Женщины были все также нарядны и праздны днем, по-прежнему столичная суета, был суровый оттенок. В Ленинграде все было иначе, война уже на всем жесткой коркой...» $[7$, c. 2].

Во время блокады К. М. Герасимова помогала рыть окопы и ходы сообщения. Вот, одно их воспоминаний из дневника: «... В тот день, когда приступили к рытью соединительного звена, начался минометный обстрел, уже были воздвигнуты шатры, но боеи наблюдатель вдруг резко опустил руку и тихо сказал: «Товарищ лейтенант, уточнено 2 немецких танка. Уточнено было 2-3 км.» ...Обстрел усилился, дело принимало какой-то оборот, лейтенант приказал поодиночке выбираться в деревню. ...Помню, как нам было страшно - совершенно пустые руки, глупая и окончательная беспомощность. Оказывается, существует жажда оружия, хотелось чего-нибудь в руки, может быть не ради битвы, а потому что обидно и страшно пропадать без какой-либо защиты, хотя бы видимости зашитыл. Вот дошла моя очередь выскакивать на верх на свист мины. Это все равно, что выскочить из собственной кожи. Выскочила и побежала, как- то стыдно бежать, согнувшись, и делать пьяные петли, побежала напролом задними дворами на другой конеи деревни» [7, с. 5].

Следует обратить внимание и на фотоисточники архивного фонда К. М. Герасимовой. Фотоматериал представлен фотографиями из этнографических экспедиций, фотографиями дацанов, шаманских обрядов, фотоматериалы по буддийскому искусству, командировок. Весь материал условно можно разделить на две группы: фотографии, сделанные лично Ксенией Максимовной и те, на которых она запечатлена сама. К примеру, в деле с личными фотоальбомами К. М. Герасимовой сохранился фотоальбом, датированный 1907 г., который принадлежал матери - А. И. Герасимовой.

Таким образом, документы из личного архивного фонда К. М. Герасимовой являются ценными историческим источниками. Они раскрывают нам научную и общественную деятельность выдающегося ученого и дают представление о развитии отечественной науки и становление личности К. М. Герасимовой как ученого.

\section{Список литературь}

1. Мальишева С.Ю. Основы архивоведения. Казань, 2002. 166 с.

2. Болсохоева Н. Д. Ксения Максимовна Герасимова (1919-2011) // Восток. Афро-азиатские общества: история и современность. 2012. № 4. C. 228-233.

3. ЦВРК ИМБТ СО РАН ЛАФ 41. ОП. 1 Л. $1-63$.

4. Кириченко С. В., Балдано М. Н. Личное дело ученого как исторический источник (К 95летию со Дня рождения доктора исторических наук, профессора Г. Л. Санжиева) // Вестник Бурятского научного центра Сибирского отде- 
ления Российской академии наук. 2019. № 4 (36). С. 138-146.

5. ЦВРК ИМБТ СО РАН ЛАФ 41. ОП. 1 Д. 3 Л. 1-27.

6. Эрдынеева С. Э. Герасимова К..

$\mathrm{O}$ концепции экспозиции Музея истории Буря- тии им. М. Н. Хангалова // Современные тенденции в развитии музеев и музееведения. Новосибирск, 2020. С. 204-210.

7. ЦВРК ИМБТ СО РАН ЛАФ 41. ОП. 1 Д. 15 Л. 1-32.

УДК 314.544.5: 793.3

DOI: $10.32340 / 2514-772 X-2021-1-19-22$

О. Н. Вернигора

Алтайский государственный институт культуры (Барнаул, Россия) vernigora_olga@mail.ru

\section{РУССКАЯ ТРАДИЦИОННАЯ КУЛЬТУРА КАК ИСТОЧНИК РАЗВИТИЯ НАПРАВЛЕНИЯ СОВРЕМЕННОГО ТАНЦА «ФОЛК»}

Аннотация. Идея коллаборации традиционной русской культуры и современного танца через смыслы, образы, лексику, пластические мотивы вне сомнений существует и находится в постоянном развитии. В статье рассматривается направление современного танца «фолк». Приводятся примеры хореографических спектаклей, которые были созданы постановщиками в данном направлении. Выявлена необходимость изучения русской традиционной культуры в целом, и традиционной культуры Алтайского края студентами, обучающимися современной хореографии. Актуализируется вопрос о необходимости изучения современного танца «фолк» в рамках учебной дисциплины «Мастерство хореографа» образовательных учреждений высшего образования в сфере культуры.

Ключевые слова: культурное наследие, Алтайский край, современный танеи, новые формы современного таниа, направление «фолк», спектакль, учебный процесс, дисииплина «Мастерство хореографа».

В практике современного танца существуют формы, основанные на танцевальном фольклоре, которые включают в свой танцевальный язык интерпретированные фольклорные движения, пластические мотивы, традиционные темы и сюжеты.

Современный танец в России не стал исключением. На его развитие активно влияет русская традиционная культура. Российские хореографы обращаются к фольклорному материалу не только для поиска новых телесных возможностей, но и как к источнику новых идей для пластических высказываний.

Достаточно подробный анализ развития направления «фолк» в современном танце осуществлен в исследованиях С. В. Устяхина, А. С. Поляковой $[1,2]$. В частности, А. С. Полякова выдвигает тезис о необходимости включения данного направления в учебный процесс в рамках учебной дисциплины «Мастерство хореографа». Преподавание дисциплины «Мастерство хореографа» в вузах культуры в области современного танца осуществляется педагогами в настоящее время основывается исключительно на индивидуальной интерпретации дан- ной темы. Автор так же находится в эксперименте, и, преподавая эту дисциплину обучающимся хореографического факультета Алтайского государственного института культуры в течение нескольких лет, руководствуется прежде всего личным опытом.

Во второй половине XX века в России появилось большое разнообразие новых направлений танца, отличающихся от классического и народного танцев. Это были различные формы современного танца - джаз танец, модерн, contemporary dance, контактная импровизация, фолк-модерн и другие формы. Джазовый танец, весьма распространенный в Америке, в России не получил столь широкого распространения в силу различных причин: это менталитет, более суровый климат, сдержанные эмоции. Танец модерн существует как формы модерн-балета в профессиональных балетных театрах, практически отсутствует в любительских хореографических коллективах. Но, пришедший в Россию из стран Запада, современный танец (contemporary dance) активно развивается как в профессиональных театрах, так и в любительских коллективах. Почему так происходит? По мнению 